УДК 556.38

DOI: $10.31660 / 0445-0108-2019-2-17-27$

Гидрогеологические условия захоронения сточных вод на территории Новопортовского месторождения

\author{
В. А. Бешенцев ${ }^{1}$, Т. В. Семенова ${ }^{1}$, Ю. И. Сальникова ${ }^{2 *}$, С. В. Воробьева ${ }^{1}$ \\ ${ }^{I}$ Тюменский индустриальный университет, г. Тюмень, Россия \\ ${ }^{2}$ Западно-Сибирский институт проблем геологии нефти и газа Тюменского инду- \\ стриального университета, г. Тюмень, Россия \\ *e-mail: salnikova.julja@rambler.ru
}

Аннотация. На нефтепромыслах севера Западной Сибири образуются значительные объемы жидких промышленных и хозяйственно-бытовых отходов, для многих из которых надежные методы очистки и утилизации в настоящее время отсутствуют. Обеспечить длительную изоляцию таких отходов от гидросферы и биосферы на поверхности Земли весьма сложно. Подземное захоронение в глубокие горизонты (недра Земли) является одним из способов предотвращения их отрицательного воздействия на окружающую среду и здоровье населения.

Ключевые слова: апт-альб-сеноманский гидрогеологический комплекс; Западно-Сибирский мегабассейн; сточные воды; загрязнение; обезвреживание; утилизация; поглощающий горизонт; экологическая безопасность

\title{
Hydrogeological condition of wastewater disposal in the territory of the Novoportovsky oil and gas condensate field
}

\section{Vladimir A. Beshentsev ${ }^{1}$, Tatyana V. Semenova ${ }^{1}$, Yulia I. Salnikova ${ }^{2 *}$, Seema V. Vorobjeva ${ }^{1}$}

${ }^{I}$ Industrial University of Tyumen, Tyumen, Russia

${ }^{2}$ West Siberian Institute of Oil and Gas Geology of Industrial University of Tyumen, Tyumen, Russia

*e-mail: salnikova.julja@rambler.ru

Abstract. Significant amounts of liquid industrial and domestic waste are generated at oil fields in the north territory of Western Siberia. There are currently no reliable methods of purification and utilization for many of them. It is very difficult to ensure long-term isolation of the waste from the hydrosphere and biosphere on the Earth. Underground disposal of wastewater in deep horizons (depths of the Earth) is one way to prevent from their negative impact on the environment and public health.

Key words: the Aptian-Albian-Cenomanian hydrogeological complex; the West Siberian megabasin; wastewater; pollution; neutralization; utilization; absorbing horizon; environmental safety 


\section{Введение}

Жидкие промышленные и хозяйственно-бытовые стоки в значительных объемах образуются при эксплуатации нефтегазовых промыслов, являются основной причиной загрязнения природной среды. Надежное и эффективное их удаление одна из важнейших народно-хозяйственных проблем, от решения которой зависит предотвращение все возрастающего загрязнения почв, поверхностных и подземных вод, воздушного бассейна. Одним из основных решений этой проблемы является закачка стоков в глубокие водоносные горизонты $[1,2]$.

У данного метода имеются как сторонники, так и противники, поскольку подземное захоронение сточных вод в глубокие водоносные горизонты - не лучший способ их удаления, но по сравнению с поверхностным складированием отходов в накопителях и их сжиганием он имеет определенные преимущества.

Вместе с тем при подземном захоронении возникает опасность загрязнения пресных подземных вод, используемых для хозяйственно-питьевого водоснабжения. Наряду с этим подземное захоронение имеет существенные ограничения в количестве закачиваемых стоков, так как таким способом могут удаляться лишь сравнительно небольшие объемы загрязненных и токсичных отходов. Поэтому, по мнению ряда специалистов [3], подземное захоронение стоков - это не радикальный способ удаления, а вынужденная мера ограниченного применения по отношению к неочищенным, сильнозагрязненным и токсичным стокам.

Исходя из этого, при выборе поглощающего горизонта для закачки сточных вод в недра, важно соблюдать ряд требований, таких как надежная изоляция пластаколлектора от выше- и нижележащих водоносных горизонтов, высокие фильтрационно-емкостные свойства пород-коллекторов, оптимальная глубина залегания поглощающего горизонта, отсутствие вод для хозяйственно-питьевого, лечебного, промышленного и других видов использования ${ }^{1,2,3}$. Основными вопросами при проведении этих видов работ являются гидрогеологические условия поглощающего горизонта и химическая совместимость пластовых и закачиваемых стоков. Данные вопрось рассмотрены на примере Новопортовского нефтегазоконденсатного месторождения.

Новопортовское месторождение в административном отношении расположено на территории Ямальского района Ямало-Ненецкого автономного округа. Административный центр района - п. Яр-Сале. Месторождение находится в 360 км к северо-востоку от г. Салехарда и в 30 км на северо-запад от п. Новый Порт.

Месторождение открыто в 1964 г., в 2012 г. введено в опытно-промышленную разработку и в 2016 г. введено в промышленную разработку. Ближайшие разрабатываемые месторождения - Бованенковское, Ямбургское, Заполярное [4, 5].

В тектоническом отношении Новопортовское месторождение приурочено к Новопортовскому КП, занимающему большую часть Новопортовской крупной брахиантиклинали, структур II и III порядка, которые, в свою очередь, подчинены положительной структуре I порядка - Южно-Ямальскому мегавалу. Последний окружен отрицательными структурами I порядка - Байдарацким и Парусным мегапрогибами.

Интересно, что по данным сейсмогеологических исследований месторождения [6], на протяжении всего времени развития территория в целом испытывает тенденцию к относительному воздыманию, особенно в кайнозое. Анализ материалов 3D-сейсмики свидетельствует о развитии на площади разнонаправленных

${ }^{1}$ РД 51-31323949-48-2000. Методическое руководство. Гидрогеологический контроль на полигонах закачки промышленных сточных вод. ООО «ИРЦ Газпром» / Под ред. В. П. Ильченко. - М., 2002. - 122 с.

${ }^{2}$ Каменев А. П. РД 00158758-182-94. Методические рекомендации по обоснованию выбора поглощающих горизонтов и проектированию закачки промстоков на газовых предприятиях Западной Сибири. - Тюмень, 1995. - 100 с.

${ }^{3}$ СТО РД Газпром 39-1.13-087-2003. Методические рекомендации по обоснованию выбора поглощающих горизонтов и проектированию закачки сточных вод на объектах ОАО «Газпром» в Западной Сибири. - М.: ИРЦ Газпром, 2003. 
разрывных и трещинных нарушений различной амплитуды. Основной разлом, трассируемый на временных разрезах от ОГ ГХМ 1 до ОГ А, разделяет площадь работ на западную и восточную части.

Как и на всех газоконденсатных промыслах Ямало-Ненецкого нефтегазодобывающего региона, на Новопортовском месторождении закачка сточных вод планируется внутри контура газоносности (под разрабатываемую газоконденсатную залежь сеномана ПК 1 ) в отложения альб-сеноманского возраста. В качестве поглощающего горизонта рассмотрены проницаемые породы марресалинской свиты в интервале пластов ПК - ПК . Мощность поглощающего горизонта составляет 194,0-255,0 м (в среднем 217,8 м).

\section{Объект и методы исследования}

Целевым объектом исследований является апт-альб-сеноманский гидрогеологический комплекс, поэтому в данной работе основное внимание уделяется его гидрогеологическим особенностям.

В гидрогеологическом отношении исследуемое месторождение приурочено к северной части Западно-Сибирского мегабассейна ${ }^{4,5}$, к мезозойскому гидрогеологическому бассейну [7]. Принадлежность исследуемой территории к зоне преимущественно сплошного распространения многолетнемерзлых пород, как в плане, так и в разрезе имеет определяющее значение для характера распространения подземных вод, их режима, динамики и химического состава. Результаты исследований, описанные в данной работе, касаются условий формирования подземных вод мезозойского гидрогеологического бассейна, которые во многом определяют условия нефтегазообразования.

\section{Результаты}

Апт-альб-сеноманский гидрогеологический комплекс характеризуется разрезом, представленным частым переслаиванием песчаников с опесчаненными глинами.

Полученные в результате исследований данные позволяют говорить, что отложения исследуемого гидрогеологического комплекса обладают высокими коллекторскими свойствами. Полученные по данным геофизических исследований скважин (ГИС) средневзвешенные по эффективной мощности параметры коллекторов в интервале альб-сеноманских отложений (пласты ПК $-П K_{9}$ ) по поисковоразведочным скважинам Новопортовского месторождения имеют следующие значения: $K_{n}=31,5 \%, K_{n p}=1878,75$ мД. Средневзвешенное значение водопроводимости по месторождению составляет $254,3 \mathrm{~m}^{2} /$ сут. Коэффициент пьезопроводности равен $11,22 \cdot 10^{5} \mathrm{M}^{2} /$ сут [8].

Воды высоконапорные, водообильность комплекса в целом значительная. Дебит водозаборной скважины 2в Новопортовской при опытной откачке из отложений пластов ПК - ПК 9 составил 652-681 м³/сут при динамическом уровне 2,2-23,3 м. При испытании разведочных скважин притоки из исследуемого интервала не превысили 7,5-20,2 м³/сут (скв. 108 и 140) при среднем динамическом уровне (СДУ) равном 548-355 м (табл. 1).

Описание пластовых вод отложений марресалинской свиты в районе работ приводится по результатам анализов восьми кондиционных проб. Непосредственно на Новопортовском месторождении отобраны две устьевые пробы из водозаборной скв. 2в (интервал 830-880 м) и пять глубинных из скважин 3Пг (860-922 м)

${ }^{4}$ Гидрогеоэкологический мониторинг в процессе закачки сточных вод на полигоне КОС ПБ ГП-1 Бованенковского НГКМ. Этап 1. Отчет о результатах опытно-промышленной закачки сточных вод в водоносную часть сеноманской залежи на КОС ПБ ГП-1 Бованенковского НГКМ: Отчет о НИР / рук. В. Т. Цацульников; ООО «ТюменНИИгипрогаз»; Тюмень, 2010.

${ }^{5}$ Каменев А. П. РД 00158758-182-94. 
и 4Пг (810-860 м). Одна устьевая проба отобрана на Хамбатейском месторождении из разведочной скв. 50 (1 016-1 021 м).

таблица 1

Гидрогеологические параметры апт-альб-сеноманского гидрогеологического комплекса Новопортовского месторождения

\begin{tabular}{|c|c|c|c|c|c|}
\hline $\begin{array}{c}\text { Номер } \\
\text { скв. }\end{array}$ & $\begin{array}{c}\text { Интервал } \\
\text { испытания, м }\end{array}$ & $\frac{\mathrm{Qв}}{\mathrm{QH}}, \mathrm{m}^{3} /$ сут & СДУ, м & $\frac{\text { Тпл., }{ }^{\circ} \mathrm{C}}{\text { Нзам, }}$ & Нст, м \\
\hline 61 & $933-940$ & $\frac{11,1}{-}$ с ФБР & 842 & $\frac{28}{930}$ & 71,5 \\
\hline 108 & $896-900$ & $\frac{7,5}{0,2}$ & 548 & $\frac{27}{890}$ & - \\
\hline 140 & $901-904$ & $\frac{20,2}{-}$ & 355 & $\frac{26}{902}$ & 36 \\
\hline
\end{tabular}

Важно, что используемые данные подтверждают соответствие химического состава вод гидрохимической обстановке комплекса в пределах Ямальской нефтегазоносной области $[9,10]$. Тип вод по В. А. Сулину - гидрокарбонатно-натриевый с коэффициентом $\mathrm{rNa} / \mathrm{rCl}=1,02-1,14$ и минерализацией $5,7-9,1$ г/дм ${ }^{3}$. Водородный показатель $(p H)$ изменяется от 7,1 до 8,1. Плотность вод - 1,003-1,006 г/ $\mathrm{cm}^{3}$.

В ионно-солевом составе преобладают хлор (84,7-95,9\%-экв) и натрий (90,8-97,4 \%-экв). Содержание кальция составляет 1,3-5,9 мг-экв/дм³, магния 0,7-1,5 мг-экв/дм ${ }^{3}$, гидрокарбоната — 4,0 мг-экв/дм³ (Хамбатейское месторождение) и 7,2-16,8 мг-экв/дм ${ }^{3}$ (Новопортовское месторождение). В пробах обнаружен карбонат-ион (до 2,4-4,8 мг-экв/дм³ ) и сульфат-ион (до 0,1 мг-экв/дм³).

Определены следующие микрокомпоненты: йод - не более 0,9 мг/дм ${ }^{3}$ (Новопортовское месторождение) и 8,0 мг/дм ${ }^{3}$ (Хамбатейское месторождение), бром от 21,3 до 42,2 мг/дм ${ }^{3}$, бор - от 0,05 до 6,5 мг/дм ${ }^{3}$, фтор - 0,6-1,9 мг/дм³.

Водорастворенный газ метановый. Определения газонасыщенности вод при испытании поисково-разведочных скважин единичны: в отложениях марресалинской свиты на Каменномысском месторождении ее величина составила $2,6 \mathrm{~m}^{3} / \mathrm{m}^{3}$, яронгской свиты на Новопортовском месторождении (пласт $\left.\mathrm{XM}_{1}\right)-1,3-1,8 \mathrm{~m}^{3} / \mathrm{m}^{3}$. Пластовые температуры в интервале пород альб-сеноманского возраста от 24,5 до $28{ }^{0} \mathrm{C}$.

Требования к составу и качеству закачиваемых стоков и их характеристика

Утилизируемые сточные воды перед закачкой в поглощающий пласт-коллектор должны пройти соответствующую подготовку для предотвращения призабойной зоны, кольматации приемной части ствола поглощающей скважины, отложения солей в пласте, развития микроорганизмов и, как следствие, процессов образования сероводорода, коррозии оборудования и других осложнений.

Основные требования к составу и качеству закачиваемых сточных вод нормируются ОСТ 39-225-88 ${ }^{6}$ и СТО Газпром 2-1.19-049-2006 ${ }^{7}$. В связи с отсутствием результатов химического анализа флюидов Новопортовского месторождения, под-

${ }^{6}$ ОСТ 39-225-88. Вода для заводнения нефтяных пластов. Требования к качеству. Введ. 1990-07-01. - 10 с

${ }^{7}$ СТО Газпром 2-1.19-049-2006. Подготовка сточных вод к закачке в поглощающий горизонт и экологический мониторинг при подземном захоронении сточных вод на нефтегазовых месторождениях ОАО «Газпром» севера Западной Сибири. - М.: ОАО «Газпром», 2006. -53 c. 
лежащих закачке, мы использовали данные химических анализов сточных вод Ямсовейского месторождения с привлечением материалов соседних действующих участков - Ямбургское, Бованенковское, Заполярное ${ }^{8}$ месторождения [11, 12]. Сравнительная характеристика результатов химического анализа воды в соответствии с нормативными документами приведена в таблице 2.

Таблица 2

Сравнительная характеристика результатов химического анализа воды в соответствии с ОСТ 39-225-88 и СТО Газпром 2-1.19-049-2006

\begin{tabular}{|c|c|c|c|}
\hline \multirow{2}{*}{$\begin{array}{l}\text { Показатель } \\
\text { качества }\end{array}$} & \multicolumn{2}{|c|}{ Нормируемый показатель } & \multirow{2}{*}{$\begin{array}{l}\text { Фактическое } \\
\text { содержание }\end{array}$} \\
\hline & OCT 39-225-88 & $\begin{array}{c}\text { СТО Газпром } \\
2-1.19-049-2006\end{array}$ & \\
\hline $\begin{array}{l}\text { Водородный } \\
\text { показатель (pH) }\end{array}$ & $4,5-8,5$ & $7-8$ & $6,7-12,8$ \\
\hline $\begin{array}{l}\text { Содержание растворен- } \\
\text { ного кислорода, мг/дм³ }\end{array}$ & Не более 0,5 & Не более 0,5 & $0-0,29$ \\
\hline $\begin{array}{l}\text { Содержание } \\
\text { сероводорода, мг/дм }{ }^{3}\end{array}$ & $\begin{array}{l}\text { В воде, нагнетаемой в продук- } \\
\text { тивный коллектор, пластовые } \\
\text { воды, которые не содержат серо- } \\
\text { водород или содержат ионы } \\
\text { железа, сероводород должен } \\
\text { отсутствовать }\end{array}$ & $\begin{array}{l}\text { Не более } \\
15 \mathrm{мг} / \text { дм }^{3}\end{array}$ & $0-2,45$ \\
\hline $\begin{array}{l}\text { Содержание ионов } \\
\text { трехвалентного железа }\end{array}$ & $\begin{array}{l}\text { При заводнении продуктивных } \\
\text { пластов, содержащих сероводо- } \\
\text { род, устанавливается возмож- } \\
\text { ность образования сернистого } \\
\text { железа, необходимы мероприя- } \\
\text { тия для удаления ионов трехва- } \\
\text { лентного железа }\end{array}$ & $\begin{array}{c}\text { Содержание } \\
\text { ионов } \mathrm{Fe}^{2+} \\
\text { не более } 3 \mathrm{мг} / \text { дм }^{3}\end{array}$ & $\mathrm{Fe}_{\text {общ }} 0,37-7,91$ \\
\hline $\begin{array}{l}\text { Содержание } \\
\text { нефтепродуктов, мг/дм³ }\end{array}$ & Не более 50 & Не более 150 & $1,1-61,7$ \\
\hline $\begin{array}{l}\text { Содержание механиче- } \\
\text { ских примесей, мг/дм }\end{array}$ & Не более 50 & Не более 300 & $57,0-126,0$ \\
\hline $\begin{array}{l}\text { Содержание } \\
\text { метанола, г/дм³ }\end{array}$ & Не нормируется & $\begin{array}{c}\text { Не более } 40 \\
\left(40000 \mathrm{мг} / \text { дм}^{3}\right)\end{array}$ & - \\
\hline $\begin{array}{l}\text { Содержание ТЭГ } \\
\text { (ДЭГ), г/дм }{ }^{3}\end{array}$ & Не нормируется & $\begin{array}{c}\text { Не более } 1 \\
\left(1000 \mathrm{Mr} / \text { дм}^{3}\right)\end{array}$ & - \\
\hline $\begin{array}{l}\text { Набухаемость } \\
\text { глинистых минералов } \\
\text { поглощающего пласта }\end{array}$ & $\begin{array}{l}\text { По мере организации закачки } \\
\text { воды набухаемость глин коллек- } \\
\text { торов в закачиваемой воде не } \\
\text { должна превышать значения их } \\
\text { набухаемости в воде на первона- } \\
\text { чальной стадии освоения место- } \\
\text { рождения }\end{array}$ & Отсутствует & $\begin{array}{l}\text { Набухание глинистых } \\
\text { минералов в коллек- } \\
\text { торах не происходит в } \\
\text { любых пропорциях } \\
\text { смеси (пласты ПК } \\
\text { ПК-9, } \\
\text { 8-9) }\end{array}$ \\
\hline $\begin{array}{l}\text { Совместимость } \\
\text { закачиваемых вод }\end{array}$ & $\begin{array}{l}\text { При контакте в пластовых } \\
\text { условиях закачиваемой воды } \\
\text { с пластовой водой и породой } \\
\text { коллектора может быть допуще- } \\
\text { но снижение фильтрационной } \\
\text { характеристики }\end{array}$ & Совместимы & $\begin{array}{l}\text { Воды продуктивных } \\
\text { пластов совместимы, } \\
\text { но возможно незначи- } \\
\text { тельное выпадение } \\
\text { осадка }\left(11-32 \text { мг/дм }{ }^{3}\right)\end{array}$ \\
\hline
\end{tabular}

${ }^{8}$ Гидрогеоэкологический мониторинг в процессе закачки ...

№ 2, 2019 Нефть и газ 
Продолжение таблицы 2

\begin{tabular}{|c|c|c|c|}
\hline \multirow{2}{*}{$\begin{array}{c}\text { Показатель } \\
\text { качества }\end{array}$} & \multicolumn{2}{|c|}{ Нормируемый показатель } & \multirow{2}{*}{$\begin{array}{l}\text { Фактическое } \\
\text { содержание }\end{array}$} \\
\hline & OCT $39-225-88$ & $\begin{array}{c}\text { СТО Газпром } \\
2-1.19-049-2006\end{array}$ & \\
\hline $\begin{array}{l}\text { Коррозионная } \\
\text { активность, мм/год }\end{array}$ & $\begin{array}{l}\text { При коррозионной активности } \\
\text { воды свыше } 0,1 \text { мм/год } \\
\text { необходимо предусматривать } \\
\text { мероприятия по антикоррозион- } \\
\text { ной защите трубопроводов и } \\
\text { оборудования }\end{array}$ & Не более 0,2 & $\begin{array}{c}\text { Высоко- } \\
\text { агрессивные } \\
\text { воды }\end{array}$ \\
\hline $\begin{array}{l}\text { Фильтрационная } \\
\text { характеристика, \% }\end{array}$ & $\begin{array}{l}\text { При снижении коэффициента } \\
\text { приемистости нагнетательных } \\
\text { скважин с начала закачки воды } \\
\text { на } 20 \% \text { следует проводить рабо- } \\
\text { ты по восстановлению фильтра- } \\
\text { ционной характеристики приза- } \\
\text { бойной зоны и при необходимо- } \\
\text { сти улучшать качество закачи- } \\
\text { ваемой воды }\end{array}$ & Не более 20 & $\begin{array}{l}\text { Снижение коэффи- } \\
\text { циента приемистости } \\
\text { нагнетательных сква- } \\
\text { жин не наблюдается }\end{array}$ \\
\hline $\begin{array}{l}\text { Наличие сульфат- } \\
\text { восстанавливающих } \\
\text { бактерий (СВБ) }\end{array}$ & $\begin{array}{l}\text { Не допускается присутствие } \\
\text { СВБ в воде, предназначенной для } \\
\text { закачки в пласты, и воде, } \\
\text { содержащей сероводород }\end{array}$ & Отсутствует & Отсутствует \\
\hline
\end{tabular}

В состав закачиваемых стоков рассматриваемого месторождения, подлежащих закачке, входят подтоварные воды, не задействованные в системе поддержания пластового давления, дождевые, бытовые, производственные стоки, а также осветленная фаза жидких отходов бурения. Смесь данных флюидов характеризуется составом и качеством входящих в нее компонентов, соотношение которых во времени может изменяться, поэтому предсказать состав закачиваемого флюида с вероятностью $100 \%$ не представляется возможным.

Подтоварные воды представляют собой смесь вод нефтегазоносных отложений, добываемых совместно с углеводородным сырьем. Чаще всего подтоварные воды близки по химическому составу и типовой принадлежности к пластовым водам продуктивных отложений.

Воды первоочередных объектов разработки (пласты $\mathrm{HП}_{2-3}, \mathrm{HП}_{4}, \mathrm{H \Pi}_{5}{ }^{1}, \mathrm{ЮH}_{2-6}$ ) хлоридные натриевые по химическому составу, гидрокарбонатно-натриевого типа (по В. А. Сулину), значения минерализации изменяются от 5,4 до 14,3 г/дм ${ }^{3}$, в основном нейтральные, реже слабощелочные или умеренно щелочные, $p H=6,2-8,9$, общая жесткость изменяется от 1,0-2,4 (танопчинская свита) до 5,5-9,5 мг-экв/дм реже выше (тюменская свита), содержание кальция преобладает над содержанием магния. Количество гидрокарбонатов изменяется от 12,6 до 47,2 мг-экв/дм ${ }^{3}$, в водах присутствуют сульфаты $(0,1-2,5$ мг-экв/дм³ $)$ и карбонаты $\left(0,8-7,6\right.$ мг-экв/дм $\left.{ }^{3}\right)$. Воды пластов напорные, термальные, газонасыщенные, водорастворенный газ метанового состава.

Бытовые стоки на месторождении образуются в процессе использования пресных вод хозяйственно-питьевого назначения. Состав и свойства стоков близки к пресным поверхностным водам питьевого назначения. Поверхностные воды в районе месторождения маломинерализованные с низкой жесткостью, гидрокарбонатные по химическому составу, слабокислые по водородному показателю.

Производственные стоки образуются в процессе производственнотехнологических мероприятий, могут содержать стоки с компрессорной установки, стоянки пожарной техники, приточной вентиляционной камеры, стоки с материально-технического склада, от промывки фильтров, с водонапорной станции и др.

Дождевые стоки - это сточные воды, образующиеся при таянии снега, льда, града или дождя, отводятся, как правило, через систему ливневой канализации. По своему составу они близки к пресным поверхностным водам. 
Жидкие отходы бурения образуются в процессе бурения, ремонта и других мероприятий, проводимых в скважинах; представляют собой многокомпонентную смесь с высоким содержанием механических примесей, нефтепродуктов и химических реагентов. Для закачки в недра жидкие отходы бурения подвергаются осветлению, в результате которого в них значительно снижается содержание механических примесей.

По значению водородного показателя $(p H)$ закачиваемые стоки в большинстве своем соответствуют установленным нормам, однако в некоторых случаях отмечаются слабокислые ( $p H=5,1$ - Ямбургское месторождение), щелочные или сильнощелочные ( $p H=12,8$ - Ямсовейское месторождение) воды, $p H$ которых превышает установленные значения. Для нормирования содержания ионов водорода необходимо подкисление или подщелачивание воды в зависимости от активной реакции среды.

Содержание растворенного кислорода, возрастающее в случае контакта с атмосферой, в закачиваемом флюиде изменяется от 0,0 до $0,29 \mathrm{Mг} /$ дм $^{3}$. В дальнейшем для его нормирования необходимо отслеживать концентрацию данного показателя, в случае действительного присутствия необходима соответствующая водоподготовка (десорбция нефтяным газом, «холодная» вакуумная деаэрация, связывание реагентами-восстановителями).

Содержание сероводорода на исследуемом месторождении изменяется от 0,0 до 2,45 мг/дм ${ }^{3}$, его присутствие связано с процессами вторичной сульфатредукции, возникающей в процессе разложения нефтепродуктов, содержащихся в жидкости.

Количество общего железа содержится в концентрациях от 0,37 до 7,91 мг/дм³; такое его количество при отсутствии в пластовых водах сероводорода и кислорода не окажет существенного влияния на приемистость поглощающих скважин. Однако в случае высокого содержания в закачиваемых стоках сероводорода и ионов железа (III) рекомендуется дополнительная очистка стоков с применением химических реагентов.

Количество взвешенных частиц и нефтепродуктов в закачиваемых водах согласно ОСТ 39-225-88 9 определяется с учетом коллекторских свойств поглощающего горизонта. Для эксплуатационного объекта Новопортовского нефтегазоконденсатного месторождения со средневзвешенным по эффективной мощности значением $K_{n p}=1878,75$ мД (по данным ГИС) допустимое содержание механических примесей и нефтепродуктов составляет 50 мг/дм ${ }^{3}$. В промышленных и хозяйственно-бытовых стоках соседних месторождений их количество колеблется в широком диапазоне значений, но в большинстве случаев не превышает установленные нормы.

Содержание метанола и триэтиленгликоля не превышает установленные нормы.

Содержание механических примесей в закачиваемых стоках не соответствует требованиям ОСТ 39-225-88 ${ }^{10}$. В данной ситуации при технической возможности рекомендуются установка фильтра на выходе водовода к устью поглощающей скважины либо проведение периодических профилактических мероприятий по удалению механических примесей и продуктов коррозии из системы водоводов, ведущих к устью поглощающих скважин.

Коррозионная активность закачиваемых вод может быть вызвана рядом факторов - присутствием в них растворенных кислых газов (углекислота, кислород, сероводород), высокой минерализацией, наличием механических примесей, повышенной температурой и др.

По данным соседних месторождений опыт закачки флюидов показал, что они являются высокоагрессивными, скорость коррозии составит более 0,1 мм/год. В связи с этим необходимо предусмотреть соответствующие мероприятия по борьбе с

${ }^{9}$ OCT39-225-88. - C. 5 .

${ }^{10}$ Там же. - C. 5. 
коррозией: применение ингибиторов коррозии, антикоррозионного покрытия и т. д.

Содержание ионов трехвалентного железа в случае совместного пребывания с сероводородом может вызвать образование нерастворимого осадка (сернистого железа). Для предотвращения этого рекомендуется предусмотреть мероприятия по удалению из воды сероводорода деаэрированием, связыванием химическими реагентами, ингибированием и др. ${ }^{11}$

По данным анализов стоков, закачиваемых на соседних участках, набухание глинистой составляющей пласта поглощающего горизонта в результате их закачки не прогнозируется. Химический состав закачиваемых флюидов приводится в таблице 3.

Таблица 3

\section{Химический состав закачиваемых флюидов [11]}

\begin{tabular}{|c|c|c|c|}
\hline Показатель & $\begin{array}{l}\text { Единица } \\
\text { измерения }\end{array}$ & $\begin{array}{l}\text { Хозяйственно- } \\
\text { бытовые стоки }\end{array}$ & $\begin{array}{l}\text { Производственные } \\
\text { и смешанные стоки }\end{array}$ \\
\hline $\mathrm{pH}$ & & $4,4-6,5$ & $6,1-12,8$ \\
\hline Минерализация & $\Gamma /$ дм $^{3}$ & $0,11-0,19$ & $0,06-0,33$ \\
\hline $\mathrm{Na}^{+}+\mathrm{K}^{+}$ & \multirow{8}{*}{ мг-экв/дм ${ }^{3}$} & $0,6-1,3$ & $0,02-2,1$ \\
\hline $\mathrm{Ca}^{2+}$ & & $0,4-0,5$ & $0,2-0,8$ \\
\hline $\mathrm{Mg}^{2+}$ & & $0,0-0,4$ & $0,1-1,7$ \\
\hline $\mathrm{NH}_{4}^{+}$ & & $0,1-0,6$ & $0,04-0,9$ \\
\hline $\mathrm{SO}_{4}{ }^{2-}$ & & 0 & $0,2-0,8$ \\
\hline $\mathrm{Cl}^{-}$ & & $0,6-1,1$ & $0,3-2,8$ \\
\hline $\mathrm{HCO}_{3}^{-}$ & & $0,4-1,4$ & $0,1-2,2$ \\
\hline $\mathrm{CO}_{3}{ }^{2-}$ & & 0 & $0,2-3,8$ \\
\hline $\mathrm{I}$ & \multirow{8}{*}{ мг/дм ${ }^{3}$} & 0 & $0,0-1,0$ \\
\hline $\mathrm{Br}$ & & 0 & $0,0-0,7$ \\
\hline $\mathrm{Fe}$ & & $0,25-0,82$ & $0,31-8,56$ \\
\hline TBB & & $26-53$ & $10-126$ \\
\hline $\mathrm{O}_{2}$ & & $0,0-0,3$ & $0,0-7,0$ \\
\hline НП & & $0,06-0,10$ & $0,03-61,7$ \\
\hline $\mathrm{H}_{2} \mathrm{~S}$ & & $0,0-1,50$ & $0,0-2,45$ \\
\hline $\mathrm{rNa} / \mathrm{rCl}$ & & $0,55-1,67$ & $0,02-4,47$ \\
\hline
\end{tabular}

\section{Обсуждение}

Совместимость закачиваемых флюидов с водами апт-альб-сеноманского гидрогеологического комплекса оценивается по результатам моделирования физикохимических процессов в смешиваемых водах в соответствии с ОСТ 39-225-88 ${ }^{12}$, выполненного с использованием программы «Расчет химической совместимости вод» [13]. Смешиваемые воды (в пластовых условиях поглощающего горизонта) считаются совместимыми, если количество осадка, образовавшегося при их смешении, не превышает установленные стандартами значения (не более $50 \mathrm{Mг} /$ дм $^{3}$ ).

В отсутствие анализов проб дождевых, бытовых, производственных стоков и осветленного бурового раствора нами произведен предварительный расчет химической совместимости закачиваемых подтоварных вод и пластовых вод погло-

${ }^{11}$ СТО Газпром 2-1.19-049-2006. - С. 27.

${ }^{12}$ OCT $39-225-88$. C. 5. 
щающего горизонта. При этом использованы результаты анализов следующих проб Новопортовского месторождения:

- $\quad$ пластовая вода поглощающего горизонта - пластов $П K_{5}-\Pi K_{9}$ марресалинской свиты - охарактеризована пробой из скв. 2в;

- $\quad$ пластовая вода поглощающего горизонта — пластов $\Pi K_{8}-\Pi K_{9}$ марресалинской свиты - охарактеризована пробой из скважины 4Пг;

- $\quad$ для характеристики подтоварных вод смоделирована смесь на основе пластовых вод нефтепродуктивных отложений $\left(\mathrm{HП}_{2-3}, \mathrm{HП}_{4}, \mathrm{H}_{5}{ }^{1}, \mathrm{ЮH}_{2-6}\right)$.

Расчет совместимости вод проведен при условии, что в закачиваемых водах присутствует остаточная углекислота, способная удерживать карбонаты в растворенном состоянии, а смешение вод происходит в термобарических условиях поглощающего горизонта.

Результаты моделирования показывают (табл. 4), что при увеличении доли закачиваемой воды степень насыщенности растет, давления насыщения $\mathrm{CO}_{2}$ в пласте-коллекторе недостаточно для растворения осадка.

таблица 4

\section{Результат определения возможности карбонатного осадкообразования при смешении закачиваемых и пластовых вод на Новопортовском нефтегазоконденсатном месторождении (пластовое давление - 85 атм, пластовая температура $+28{ }^{\circ} \mathrm{C}$ )}

\begin{tabular}{|c|c|c|c|c|c|c|}
\hline \multicolumn{2}{|c|}{ Доля воды в смеси, \% } & \multicolumn{3}{|c|}{$\begin{array}{c}\text { Содержание осадкообразующих } \\
\text { компонентов, г/дм }\end{array}$} & \multirow{2}{*}{$\begin{array}{l}\text { Осадок, } \\
\Gamma / \text { дм }^{3}\end{array}$} & \multirow{2}{*}{$\begin{array}{l}\text { Минерализация } \\
\text { смеси, г/дм }^{3}\end{array}$} \\
\hline $\begin{array}{c}\text { Пластовая } \\
\text { скв. 2в }\end{array}$ & $\begin{array}{l}\text { Закачиваемая } \\
\text { смесь }\end{array}$ & $\mathrm{Ca}$ & $\mathrm{Mg}$ & $\begin{array}{l}\text { Карбонатная } \\
\text { щелочь }\end{array}$ & & \\
\hline \multicolumn{7}{|c|}{ Скв. 2в, пласт ПК - -ПК 9} \\
\hline 100 & 0 & 0,026 & 0,009 & 0,729 & - & 5,73 \\
\hline 80 & 20 & 0,026 & 0,016 & 0,968 & 0,011 & 6,56 \\
\hline 60 & 40 & 0,026 & 0,023 & 1,207 & 0,019 & 7,39 \\
\hline 50 & 50 & 0,027 & 0,027 & 1,326 & 0,022 & 7,81 \\
\hline 30 & 70 & 0,027 & 0,034 & 1,565 & 0,028 & 8,64 \\
\hline 10 & 90 & 0,027 & 0,041 & 1,804 & 0,032 & 9,47 \\
\hline 0 & 100 & 0,027 & 0,045 & 1,923 & 0,034 & 9,89 \\
\hline \multicolumn{7}{|c|}{ Скв. 4Пг, пласт ПК ${ }_{8}-П К_{9}$} \\
\hline 100 & 0 & 0,081 & 0,017 & 1,012 & 0 & 7,12 \\
\hline 80 & 20 & 0,070 & 0,023 & 1,180 & 0,023 & 7,68 \\
\hline 60 & 40 & 0,059 & 0,028 & 1,348 & 0,030 & 8,24 \\
\hline 50 & 50 & 0,054 & 0,031 & 1,432 & 0,030 & 8,52 \\
\hline 30 & 70 & 0,043 & 0,037 & 1,600 & 0,028 & 9,08 \\
\hline 10 & 90 & 0,032 & 0,042 & 1,768 & 0,027 & 9,64 \\
\hline 0 & 100 & 0,026 & 0,045 & 1,852 & 0,027 & 9,91 \\
\hline
\end{tabular}


Увеличивается содержание осадкообразующих компонентов и значений минерализации, количество прогнозируемого осадка незначительное - 11-32 мг/дм³. Смоделированная закачиваемая смесь нестабильна в термобарических условиях поглощающего пласта и может выделять кальцит в количестве 27-34 мг/дм³ ${ }^{3}$ что не превышает нормируемый предел. Воды совместимы.

Из вышеизложенного можно сделать вывод о совместимости пластовых и подтоварных подземных вод на территории изучаемого месторождения.

Во всех случаях в рамках проведения мониторинга водных объектов необходимы постановка наблюдений за характером изменения приемистости скважин, документация условий проведения работ (состав закачиваемых вод, содержание нефтепродуктов и твердовзвешенных веществ), должен проводиться контроль за изменением температуры и давлением в нефтяном пласте [14].

\section{Выводы}

Гидрогеологические исследования по закачке стоков на территории месторождений Ямала показали, что закачиваемые стоки в большинстве своем совместимы с водами поглощающего апт-альб-сеноманского гидрогеологического комплекса, осадка не образуется. Опыт закачки жидких отходов бурения в данный гидрогеологический комплекс на ряде месторождений XМАО - Югры также дает положительные результаты. Исходя из этого, на нефтепромыслах севера Западной Сибири апт-альб-сеноманский гидрогеологический комплекс считается наиболее экологически безопасным и гидрогеологически целесообразным.

При этом одновременно решаются две природоохранные задачи: обезвреживание стоков и частичное восполнение снижающегося пластового давления при добыче углеводородов. При захоронении стоков в поглощающий горизонт возможны негативные факторы и явления, требующие специального гидроэкологического контроля (мониторинга) на полигонах захоронения.

\section{Библиографический список}

1. Бешенцев В. А., Семенова Т. В., Павлова Е. И. Захоронение сточных вод на нефтепромыслах Западной Сибири (на примере Ямало-Ненецкого нефтегазодобывающего региона) // Известия высших учебных заведений. Нефть и газ. - 2014. - № 5. - С. 6-10.

2. Бешенцев В. А., Семенова Т. В. Охрана подземных вод от загрязнения на полигонах закачки при захоронении промышленных стоков (на примере Ямало-Ненецкого нефтегазодобывающего региона) [Электронный ресурс] // Нефтегазовое дело. - 2014. - № 5. С. 357-374. - Режим доступа: http://dx.doi.org/10.17122/ogbus-2014-5-357-374.

3. Гольдерберг В. М., Скворцов Н. П., Лукьянчикова Л. Г. Подземное захоронение промышленных сточных вод. - М.: Недра, 1994. -282 с.

4. Оценка ресурсов и качества подземных вод Ямало-ненецкого автономного округа / И. В. Абатурова [и др.]; Институт геологии и геохимии УрО РАН. - Екатеринбург, 2000. - 394 с.

5. Бешенцев В. А., Абдрашитова Р. Н., Бешенцева О. Г. Подземные воды мезозоя в пределах месторождений, приуроченных к Ямальской нефтегазоносной области // Горные ведомости. - 2018. - № 5 - С. 44-51.

6. Солмин А. Е., Сурикова Е. С. Сравнительная сейсмогеологическая характеристика осадочного комплекса Ямальской и Гыданской нефтегазоносных областей // Трофимуковские чтения - 2017: Материалы Всеросс. молодежной науч. конф. с участием иностранных ученых / Российская академия наук, Сиб. отд-ние, Институт нефтегазовой геологии и геофизики им. А. А. Трофимука. - Новосибирск, 2017. - С. 155-158.

7. Бешенцев В. А., Семенова Т. В. Подземные воды севера Западной Сибири (в пределах Ямало-Ненецкого нефтегазодобывающего региона). - Тюмень: ТюмГНГУ, 2015. $224 \mathrm{c}$.

8. Ланшаков В. Г., Миронова Л. М. Дополнение к проекту ГРР по поискам и оценке пластов-коллекторов в отложениях апт-альб-сеноманского водоносного комплекса для закачки очищенных промышленных и хозяйственно-бытовых стоков и утилизации жидких 
отходов бурения на территории ЦПС Новопортовского нефтегазоконденсатного месторождения. - Тюмень: ТИУ, 2017.

9. Нефтегазоносные комплексы Западно-Сибирского бассейна / М. Я. Рудкевич [и др.]. - М.: Недра, 1988. - 303 с.

10. Скоробогатов В. А., Строганов Л. В., Копеев В. Д. Геологическое строение и газонефтеносность Ямала. - М.: Недра, 2003. - 352 с.

11. Саитов В. А., Сальникова Ю. И. Отчет по анализу эксплуатации полигона захоронения стоков по данным мониторинга на Ямсовейском НГКМ. - Тюмень: ТюмГНГУ, 2012.

12. Сальникова Ю. И., Бешенцев В. А., Абдрашитова Р. Н. Вопросы утилизации сточных вод на Ямсовейском нефтегазоконденсатном месторождении // Известия высших учебных заведений. Нефть и газ. - 2019. - № 1. - С. 19-29. DOI: 10.31660/0445-0108-2019-1-19-29.

13. Свидетельство о государственной регистрации программы «Расчет химической совместимости вод» в Реестре программ для ЭВМ Федеральной службы по интеллектуальной собственности № 2013616498 от 10 июля 2013 / Таранов Ю. А., Плавник А. Г., Таранова Л. В., Резанова Т. П.

14. Семенова Т. В. Проблемы совместимости пластовых и закачиваемых вод на нефтепромыслах Западной Сибири. // Известия высших учебных заведений. Нефть и газ. 2017. - № 4. - C. 34-37. DOI: 10.31660/0445-0108-2017-4-34-37.

\section{Сведения об авторах}

Бешенцев Владимир Анатольевич, д. г.-м. н., профессор кафедры геологии месторождений нефти и газа, Тюменский индустриальный университет, г. Тюмень, e-mail:makarova-olga-1958@mail.ru

Семенова Татьяна Владимировна к. г.-м. н, доиент кафедры геологии месторождений нефти и газа, Тюменский индустриальный университет, г. Тюмень, e-mail: semenovatv@tyuiu.ru

Сальникова Юлия Ивановна, заведующий сектором Западно-Сибирского инсти тута проблем геологии нефти и газа Тюменского индустриального универcuтета, 2. Тюмень, e-mail: salnikova.julja@rambler.ru

Воробьева Сима Васильевна, д. т. н., профессор кафедры техносферной безопас ности, Тюменский индустриальный универcumem, 2. Тюмень, e-mail: vorobevasv@tyuiu.ru

\section{Information about the authors}

Vladimir A. Beshentsev, Doctor of Geology and Mineralogy, Professor at the Department of Geology of Oil and Gas Fields, Industrial University of Tyumen, e-mail: makarovaolga-1958@mail.ru

Tatyana V. Semenova, Candidate of Geology and Mineralogy, Associate Professor at the Department of Geology of Oil and Gas Fields, Industrial University of Tyumen, e-mail: semenovatv@tyuiu.ru

Yulia I. Salnikova, Head of sector of the West Siberian Institute of Oil and Gas Geology of Industrial University of Tyumen, e-mail: salnikova.julja@rambler.ru

Seema V. Vorobjeva, Doctor of Engineering, Professor at the Department of Technosphere Safety, Industrial University of Tyumen, e-mail:vorobevasv@tyuiu.ru 